\title{
PEMBINGKAIAN BERITA ISU PELEMAHAN RUPIAH MENJELANG PEMILIHAN PRESIDEN 2019 PADA MEDIA ONLINE
}

\author{
MARCELLA APRIANI \\ Ilmu Komunikasi, Fakultas Komunikasi dan Bisnis \\ Universitas Telkom Bandung \\ Email : marcellaafrianny@gmail.com
}

\begin{abstract}
:
The study entitled "Framing of the News Issue of Weakening the Rupiah Ahead of Presidential Election 2019 in Media Online" aims to find out how online media news frames the issue of weakening the rupiah ahead of the presidential election. The news in this study is news that has a high popularity on the issue of the rupiah, namely the period 2 September-8 September 2018. Based on that period, four news were found through the google database. The method in this study is descriptive qualitative research method using the theory of framing analysis of Zhongdang Pan and Gerald M Kosicki. By using four structures from Pan and Kosicki namely syntactic, script, thematic, and rhetorical structures. The results of this study indicate that Kompas.com's online media news framed the news of rupiah depreciation in the political frame, it is seen the use of the word "frying" in quoting statements to describe the rise of the US dollar against the rupiah exchange rate.
\end{abstract}

Keywords : News, Online Media, Framing, News Construction

\section{PENDAHULUAN}

Menjelang Pemilihan Presiden Indonesia 2019, isu ekonomi menjadi isu yang digunakan dalam perbincangan politik (Amirullah, 2018, Hidayat, 2018). Salah satu isu yang diperbincangkan dalam politik adalah isu pelemahan rupiah. Isu ini dianggap penting karena bergerak sangat dinamis. Menurut Johansyah (2013) perang mata uang yang memanas maupun yang tak pernah reda harus menjadi salah satu fokus perhatian, dan isu rupiah merupakan isu yang paling kuat dalam isu ekonomi. Isu pelemahan rupiah bahkan sempat terpuruk pada tahun 2018 semenjak tahun 1998 (Putra, 2018). Isu rupiah pada tahun 2018 juga dianggap yang paling buruk selama 5 tahun terakhir karena mencapai angka nilai tukar sebesar 15.000 per US Dolar.

Penggunaan isu pelemahan rupiah dalam perbincangan politik dapat bermanfaat, karena isu tersebut menjadi perhatian masyarakat banyak. Hal tersebut dapat dilihat dalam data yang ditampilkan google trends. Dalam data google trends, menunjukan dimana pembahasan mengenai isu rupiah sepanjang tahun 2018, rupiah mengalami perhatian yang lebih tinggi dalam segi popularitas yang banyak diakses di media online pada tanggal 2 September hingga 8 
September 2018. Menurut Chykina dan Crabtree (2018) mengatakan bagaimana google trends dapat digunakan untuk memeriksa suatu isu penting yang dianggap sulit untuk dilakukan survei kepada massal.

Isu rupiah yang ditunjukan melalui grafik google trends, menunjukan popularitas isu pelemahan rupiah pada media online khususnya portal berita online. Hal tersebut dikarenakan dengan menggunakan kata kunci rupiah pada google, laman pertama yang muncul pada google menunjukan portal-portal berita online yang menerbi tkan pemberitaan mengenai isu rupiah. Sehingga dapat dikatakan, bahwa isu rupiah ini merupakan isu yang popular di media online dan memiliki ketertarikan bagi penggakses media online untuk mengetahui isu rupiah. Melemahnya nilai tukar rupiah terhadap dolar AS pada tahun 2018 terjadi pada tahun politik dimana Jokowi kembali maju pada Pemilihan Presiden 2019. Sehingga menurut Supratikno (2018), walaupun isu rupiah bukanlah isu politik, namun pelemahan isu rupiah terhadap dolar AS bisa dimanfaatkan oleh partai politik khususnya lawan politik Jokowi. Perbincangan isu rupiah yang terjadi pada masa jabatan Jokowi dilakukan dimulai dengan adanya pemberitaan-pemberitaan di media mengenai isu melemahnya rupiah. Menurut Sugiarto (2014) mengatakan bagaimana partai politik menggunakan media online sebagai sarana yang digunakan, sehingga lebih efektif dibandingkan dengan media cetak. Hal ini dikarenakan, pembaca yang melihat isi berita dalam media online dapat terpengaruh karena memiliki jumlah pengguna yang massif.

Menurut McQuail (2011), pemberitaan yang dilakukan oleh media memiliki peranan yang sangat penting bagi kancah politik dikarenakan memiliki fungsi sebagai penyampaian tujuan. Kemudahan yang diberikan dalam mengakses informasi kapan saja dan dimana saja, menjadi salah satu alasan banyak pembaca berita menggunakan berita online sebagai media yang diakses. Media massa seperti berita online dijadikan oleh para politisi dan pejabat negara untuk mempromosikan atau mengiklankan masing-masing politiknya agar mendapatkan dukungan bagi masing-masing partainya dari masyarakat. Hal inilah yang menjadikan media massa dan partai politik memiliki keterkaitan satu sama lain.

Media dapat menjadi subjek yang memanipulasi pernyataan atau peristiwa politik karena tekanan kepentingan ekonomi dan politik pemilik atau pengelolanya. Hal tersebut dapat terlihat dari pemberitaan yang dilakukan oleh portal berita online dengan gaya pemberitaan mereka yang berbeda-beda. Walaupun mengangkat isu yang sama yaitu rupiah, namun isu ini dapat disampaikan berbeda oleh setiap media sehingga menimbulkan perbedaan pandangan dari masyarakat yang membaca berita.

Menurut Eriyanto (2002:24) dapat dilihat melalui beberapa pendekatan untuk melihat perspektif dan ideologi media ketika melakukan penyeleksian isu atau peristiwa serta bagaimana media tersebut menyajikannya dalam sebuah berita. Hal inilah yang menjadikan media berita 
termasuk kedalam pendekatan pandangan komunikasi yaitu analisis framing. Framing yang dilakukan oleh media, tentu memiliki tujuannya masing-masing perihal pembingkaian yang dilakukan oleh media. Demikian pula yang terjadi dengan media online mengenai pemberitaan yang dilakukan khususnya membahas mengenai isu pelemahan rupiah.

Media memiliki caranya tersendiri dalam memberikan cerita atau pandangan kepada pembaca mengenai pembahasan mengenai isu pelemahan rupiah yang terjadi di Indonesia. Cara pandangan yang berbeda inilah yang akan peneliti analisis dengan menggunakan analisis framing.

Dalam penelitian ini peneliti menganalisis bagaimana pembingkaian berita yang dilakukan oleh media online. Metode yang digunakan dalam penelitian ini adalah metode penelitian kualitatif deskriptif dengan menggunakan teori analisis framing dari Pan dan Kosicki (2012). Model analisis yang diperkenalkan oleh Pan dan Kosicki ini menggunakan empat elemen struktur yaitu struktur sintaksis, skrip, tematik dan retoris untuk mengetahui pembingkaian yang dilakukan oleh media. Dengan elemen-elemen tersebut, peneliti dapat mengetahui pembingkaian yang dilakukan oleh media online.

\section{TINJAUAN PUSTAKA}

\section{Media Online}

Menurut Siregar (2005) menjelaskan bahwa media online merupakan media yang tersaji secara online di situs web internet. Media online dapat disebut juga sebagai media "generasi ketiga" setelah media cetak. Dalam media online dapat dikategorikan sebagai objek teori yaitu "media baru" yang berarti mengacu pada pengaksesan yang dapat dilakukan kapan saja, dimana saja, dalam setiap perangkat digital.

\section{Ekonomi-Politik Media}

Golding dan Murdock (1997:41) berpendapat bahwa perspektif ekonomi dan politik media berbeda dengan arus utama ilmu ekonomi dalam hal holisme, keseimbangan antara usaha kapitalis dengan intervensi publik, dan keterkaitan dengan persoalan-persoalan moralitas, seperti masalah keadilan, kesamaan, dan barang-barang yang ada di publik.

\section{Jurnalisme Online}

Menurut (Wendratama, 2017), jurnalisme online memiliki keunggulankeunggulan dibandingkan konvensional yaitu adanya keringkasan yang dibuat pada berita online dikarenakan pembaca yang memiliki waktu yang sedikit dalam membaca dan mencari tahu, harus bisa menyesuaikan diri dengan kebutuhan dan keinginan publik, berita yang diterbitkan dapat dipindai sehingga memudahkan 
pembaca, adanya kemampuan untuk menambahkan media lain seperti teks, audio, gambar, video, dan melibatkan pembaca sebagai pengguna agar pembaca merasa dirinya dihargai dan merasa puas.

\section{Berita}

Berita merupakan laporan atau pemberitahuan mengenai sebuah peristiwa aktual yang menarik perhatian orang banyak. Hadirnya teknologi secara modern menjadikan berita lebih berkembang yaitu munculnya berita online. Berita online banyak diakses oleh masyarakat juga dikarenakan kecepatan yang dapat diakses dimanapun dan kapanpun. Namun dengan kelebihan yang dimiliki tersebut, menimbulkan munculnya kurang kepercayaan terhadap berita yang diterbitkan oleh penulis berita.

Menurut Mathari (2018: 37) sumber berita dan wartawan adalah dua hal yang saling berkaitan satu sama lain dan saling membutuhkan. Wartawan mungkin hanya dapat menulis berita yang dituliskan berdasarkan asumsinya atau pendapatnya sendiri, namun tanpa sumber apapun yang dituliskan oleh seorang wartawan hanyalah sebuah opini atau karangannya secara pribadi. Sumber berita akan ditentukan oleh seorang wartawan ketika akan mulai melakukan peliputan, hal ini ditujukan untuk menghasilkan liputan yang berpihak pada kebenaran.

Menurut Harahap (2018: 47) nilai dalam sebuah berita dijadikan acuan dalam merancang, meliput, menulis berita. Hal tersebut dapat menentukan apakah berita yang dibuat dapat dibaca atau tidak oleh pembaca berita. Nilai berita atau kualitas suatu berita ditentukan oleh aktualitas, daya tarik, dan kegunaan berita bagi sebagian besar khalayak.

\section{Kontruksi Realitas}

Realitas timbul dihadapan khalayak yang membaca dikarenakan adanya framing yang timbul dan tergantung dari bagaimana peristiwa dibingkai oleh wartawan yang mempunyai frame berbeda saat menulis suatu berita sesuai dengan pandangannya atas suatu kejadian.

Publik menggunakan media sebagai sumber utama bahkan satu-satunya dalam mengetahui apa yang terjadi disekitarnya, baik yang terjadi dalam tingkat lokal, nasional maupun Internasional. Karena itulah, tidak mengherankan jika media menjadi penyebab adanya persepsi mengenai isu yang dipandang penting.

Menurut Bungin (2008) istilah konstruksi realitas terkenal sejak diperkenalkan oleh Peter L.Berger dan Thomas Luckmann melalui bukunya yang berjudul The Social Construction of Reality: A Treatise in The Sociological of Knowledge (1996). Ia menunjukan bagaimana proses sosial melalui tindakan dan interaksinya, di mana individu menciptakan secara terus-menerus suatu realitas yang dimiliki. 


\section{Analisis Framing}

Analisis framing merupakan analisis yang digunakan untuk mengetahui suatu realitas dibingkai oleh media. Bagaimana media dapat memahami realitas dan dengan cara seperti apa realitas tersebut ditandai.

Dalam perspektif komunikasi, analisis framing dipakai untuk membedah cara-cara atau ideologi media saat mengkonstruksi fakta. Analisis ini mencermati bagaimana strategi seleksi, penonjolan dan pertautan fakta ke dalam berita agar lebih bermakna dan lebih menarik pembaca dalam mengakses berita yang diterbitkan (Sobur, 2012).

Framing menurut Sobur juga sebagai metode penyajian realitas dimana suatu kebenaran tentang suatu peristiwa tidak diingkari secara total, melainkan dibelokan secara lebih halus, dengan hanya memfokuskan pada aspek-aspek tertentu saja yang menjadi fokus baik dari segi kata yang ditonjolkan, foto, atau ilustrasi lainnya.

Framing berita merupakan perpanjangan dari teori agenda setting, yaitu semacam teknik yang dipakai Jurnalis untuk melahirkan wacana yang akan ditangkap oleh khalayak. Menurut Eriyanto (2002) framing dapat terlihat dari bagaimana wartawan memilih dan memilah bagian dari realitas dan menjadikannya bagian yang penting dari sebuah teks berita. Secara teknis, seorang jurnalis tidak akan mem-framing seluruh bagian dari berita, hanya bagian dari kejadian-kejadian yang penting saja yang menjadi objek framing wartawan.

Teori analisis framing menurut Eriyanto (2002) dikategorikan sebagai empat teori analisis, yaitu teori analisis framing Murray Edelman yang menerapkan gagasan utama yang diberikan yaitu mengenai mengarahkan khalayak terhadap suatu isu dan membentuk pendapat yang dipikirkan oleh khalayak terhadap suatu isu. Teori analisis framing $X$ Robert N. Entmann menjelaskan bagaimana media melakukan penonjolan pada suatu peristiwa yang sengaja dibuat oleh pemilik media dalam menerbitkan berita yang diterbitkannya. Teori analisis framing William A Gamson menunjukkan perhatian terhadap studi gerakan sosial yang menyinggung pada studi media, dan elemen penting dari gerakan sosial. Terakhir teori analisis framing dari Zhongdang Pan dan Kosicki, teori ini menunjukkan bagaimana konstruksi realitas yang dilakukan oleh media.

\section{Pan dan Kosicki}

Pan dan Kosicki membagi perangkat framing kedalam empat elemen besar yaitu elemen sintaksis, skrip, tematik, dan retoris. Eriyanto (2002:257), sintaksis dalam gambaran umum menunjukkan susunan kata atau frase kalimat.

Dalam wacana berita, sintaksis menunjukan gambaran susunan bagian berita mulai dari headline, lead, latar informasi, sumber, penutup. Sehingga dari susunan yang teratur tersebut dapat membentuk skema yang menjadi pedoman 
bagaimana fakta hendak disusun oleh penulis berita. Dalam elemen ini dapat memberi petunjuk bagaimana wartawan memaknai suatu peristiwa dan hendak dibawa kemana berita yang diterbitkan tersebut.

Struktur elemen skrip, (Eriyanto, 2002:260) menunjukkan bukan terletak pada cara bercerita wartawan melainkan fakta yang dihadapi. Wartawan ingin agar khalayak pembaca tertarik dengan berita yang ditulis. Karenanya, peristiwa dibuat dengan mengaduk unsur emosi, menampilkan sebuah peristiwa tampak sebagai sebuah kisah.

Tematik (Eriyanto, 2002:261) menunjukkan bagaimana peristiwa yang diliput, sumber yang dikutip, dan pernyataan yang diungkapkan. Struktur ini dapat diamati dari bagaimana wartawan mengungkapkan peristiwa yang dibuat.

Struktur retoris, (Eriyanto, 2002:262) menggambarkan pilihan gaya atau kata yang dipilih oleh wartawan untuk menekankan arti yang ingin ditonjolkan oleh wartawan. Biasanya digunakan oleh wartawan untuk membuat citra, meningkatkan kemenonjolan pada sisi tertentu dan meningkatkan gambaran yang diinginkan dari suatu berita. Elemen dalam retoris yang dipakai dilihat dari leksikon, pemilihan dan pemakaian kata-kata tertentu untuk menggambarkan peristiwa.

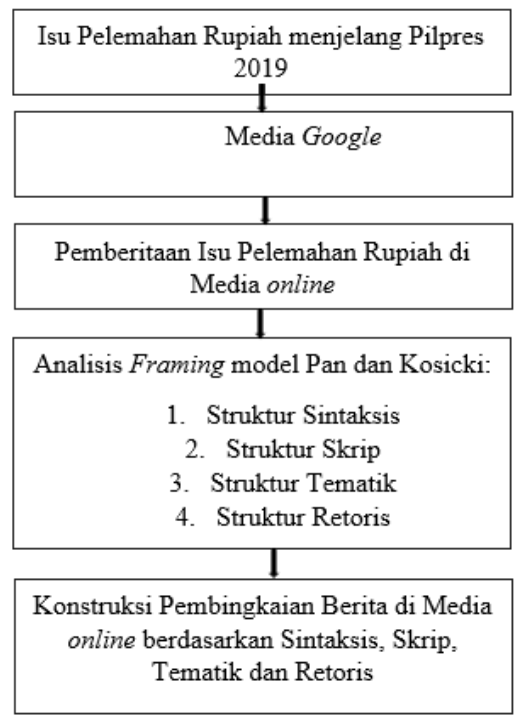

\section{METODE PENELITIAN}

Dalam penelitian ini, peneliti menggunakan metode penelitian deskriptif kualitatif dengan menggunakan teori analisis framing Zhongdang Pan dan Gerald M Kosicki. Tujuan dalam penelitian ini adalah untuk mengetahui bagaimana berita media online membingkai isu pelemahan rupiah menjelang Pilpres, maka untuk memenuhi tujuan dari peneliti, tujuan tersebut dapat diketahu dengan menggunakan metode teori analisis framing Pan dan Kosicki. Dengan model 
analisis ini, peneliti menganalisis berita dengan menggunakan empat elemen struktur sintaksis, skrip,tematik, dan retoris.

\section{HASIL DAN PEMBAHASAN}

Berdasarkan pengumpulan data yang dilakukan, peneliti menganalisis beritaberita yang ditemukan dengan menggunakan empat struktur dari masing-masing beritanya. Berikut analisis berita berdasarkan setiap struktur:

\section{A. Sintaksis}

Dilihat dari judul berita yang diterbitkan oleh media Tribunnews.com yaitu "Gubernur BI Soal Pelemahan Rupiah: Fundamentalnya Harusnya Tidak Selemah Ini”, menunjukkan kepada pembaca pemberitaan mengenai topik isu pelemahan rupiah yang mengakibatkan fundamental melemah dialami Indonesia pada waktu tersebut. Pada pemberitaannya, media Tribunnews.com menggunakan Perry Warjiyo yang menjabat sebagai Gubenur BI sebagai narasumber yang memberikan pernyataan terkait topik melemahnya rupiah dianggap merupakan sebagai narasumber yang sesuai dalam memberikan pernyataan tersebut. Gubernur BI memiliki wewenang sebagai salah satunya untuk menjaga kestabilan nilai tukar rupiah.

Pada media Liputan6.com, berita yang diterbitkan oleh Liputan6.com yaitu "3 Alasan Pelemahan Rupiah Saat Ini Berbeda dengan 1998" menunjukkan kepada pembaca bahwa pemberitaannya mengenai topik isu rupiah yang membahas faktor yang membedakan rupiah melemah tahun 1998 dengan 2018. Isi pemberitaan yang diberikan oleh media Liputan6.com menunjukkan pemberitaan alasan rupiah melemah sebanyak 3 alasan yang membedakan, hal tersebut dapat terlihat bahwa judul yang diberikan dengan isi pemberitaannya memiliki kesamaan dalam segi penyampaian informasinya. Pemilihan narasumber dalam pemberitaan di media Liputan6.com yaitu Denni Puspa selaku staf Presiden dalam bidang ekonomi, sehingga pemberitaan mengenai isu ekonomi yaitu rupiah memang sudah dalam ranahnya untuk turut memberikan pernyataan.

Pada pemberitaan di media Detik.com, judul yang diberikan yaitu "Ini Bedanya Pelemahan Rupiah 2018 dan Krismon 1998”, pada pemberitaannya wartawan ingin menunjukkan kepada pembaca bahwa pemberitaan yang ditulisnya pada media ini mengenai pelemahan rupiah tahun 2018 dengan krismon tahun 1998 memiliki perbedaan yang terlihat. Narasumber yang memberikan pernyataan pada pemberitaan ini memiliki 3 narasumber yang memang mempunyai wewenang dalam memberikan pernyataan terkait isu rupiah. Pemilihan narasumber yang lebih dari satu narasumber juga membuat pemberitaan ini semakin lengkap karena memiliki perbedaan pernyataan yang saling berkesinambungan dalam menunjukkan perbedaan pelemahan rupiah tahun 2018 dengan tahun 1998. 
Pada pemberitaan di media Kompas.com, wartawan memberikan judul "Ketua DPD Sesalkan Pelemahan Rupiah Jadi Alat Politik untuk Serang Pemerintah". Pada judul yang dituliskan, wartawan sudah memfokuskan pemberitaan yang ingin diberikan kepada pembaca mengenai isu rupiah dikaitkan dengan isu politik. Jika dilihat pada judul yang diberikan dengan isi pemberitaan pada berita ini memang menunjukkan pemberitaan yang memfokuskan pada kaitan isu rupiah dengan isu politik. Narasumber pada pemberitaan ini yaitu ketua DPD komite IV, dimana pada jabatan tersebut tidak memiliki wewenang dalam memberikan pernyataan terkait isu politik

\section{B. Skrip}

Dari struktur skrip, media Tribunnews.com Liputan6.com, Detik.com dan Kompas.com mengisahkan informasi kedalam berita yang diterbitkan memiliki kelengkapan dalam segi penyampaian informasi.

\section{Tematik}

Pada media Tribunnews.com, informasi yang dituliskan pada setiap paragraf yang diberikan dapat terlihat bahwa wartawan ingin menunjukkan informasi yang ditekankan pada pemberitaannya yaitu mengenai fundamental yang melemah karena adanya isu rupiah. hal tersebut dapat terlihat dari setiap pernyataan pada paragraf yang ditunjukkan mengenai pelemahan fundamental mulai dari data yang diberikan hingga alasan rupiah dapat melemah.

Pada media Liputan6.com, informasi yang ditekankan dari awal pemberitaannya hingga akhir pemberitaannya menunjukkan mengenai tiga poin dimana rupiah melemah tahun 2018 dengan tahun 1998 memiliki perbedaan. Pada setiap poin yang diberikan tersebut, wartawan memberikan data atau alasan yang diberikan sesuai dengan pernyataan narasumber yang memberikan informasi.

Sama halnya dengan media Liputan6.com, media Detik.com juga memberikan informasi mengenai alasan perbedaan rupiah pada tahun 2018 dengan 1998. Pada pemberitaan yang diterbitkan oleh Detik.com terlihat lebih banyak informasi yang diberikan. Selain itu pada media Detik.com juga memiliki narasumber yang lebih dari satu yang menjadikan pemberitaan ini terlihat lebih detail karena memiliki sudut pandang yang berbeda narasumber dalam memberikan pernyataan terkait alasan yang membedakan rupiah melemah tahun 2018 dengan 1998 mengalami perbedaan.

Pada media Kompas.com, wartawan mengisahkan informasi pada pemberitaannya dengan menuliskan bagaimana isu rupiah dikaitkan dengan politik. Hal tersebut dapat terlihat pada awal pemberitaannya, wartawan sudah menunjukkan bagaimana narasumber yang ada pada pemberitaan ini untuk tidak memojokkan pemerintah dengan adanya isu melemahnya rupiah. 


\section{Retoris}

Pada media Tribunnews.com, kata yang diberikan pada setiap informasinya di pemberitaannya menggunakan kata yang masih dapat dimengerti pada bahasa sehari-hari. Hanya saja ada kalimat yang diberikan oleh Tribunnews.com untuk menunjukkan kepada pembaca agar mengetahui hal yang telah dilakukan oleh BI, seperti "asal tahu saja, untuk mencegah nilai rupiah merosot lebih dalam, BI terus berada di pasar menaikkan volume intervensi baik dipasar valas maupun di pasar SBN".

Pada media Liputan6.com, ada kata yang sengaja dikutip oleh media Liputan6.com dalam memberikan informasi pada isi pemberitaannya, kata yang dikutip oleh wartawan untuk pembaca yaitu kata "modal". Dimana berdasarkan EYD, jika memiliki kata atau istilah dalam sebuah kalimat yang diberikan tanda petik menunjukkan bahwa kata tersebut memiliki arti khusus. Hal tersebut menunjukkan bahwa kata "modal" yang dikutip oleh wartawan pada pemberitaannya memiliki arti khusus tersendiri bagi wartawan yang ingin pembaca ketahui.

Pada media Detik.com, kata maupun gaya bahasa yang dipakai pada pemberitaannya masih dapat dimengerti dan tidak ada arti khusus yang diberikan seperti kutipan pada isi pemberitannnya. Hanya saja pada pemberitaan yang diberikan oleh Detik.com memberikan gambar yaitu seperti animasi, dimana jika diperhatikan pada isu melemahnya rupiah yang dibahas dengan narasumber yang memberikan pernyataan, tidak memiliki kesinambungan dengan gambar yang diberikan pada berita ini.

Pada media Kompas.com, terdapat kata "menggoreng" yang dituliskan oleh wartawan dalam menggambarkan isu kenaikan dolar AS. Berikut kalimat yang dituliskan oleh wartawan "Oesman meminta semua pihak tidak terusmenerus menggoreng isu kenaikkan dollar Amerika Serikat (AS) dan memojokkan pemerintah". Kata "menggoreng" disini sedikit membingungkan, karena jika dilihat pada kamus KBBI memiliki pengertian yang sama saja dengan pengertian dalam segi memasak. Sedangkan menurut Anto (2018), mengatakan dimana adanya sentimen yang sengaja diciptakan untuk membuat suasana semakin lebih memanas dan saling mencurigai antar masyarakat. Hal tersebut juga berlaku bagi pernyataan Oesman yang dituliskan oleh wartawan yang memberikan pernyataan kata "menggoreng" yang ada pada pemberitaan untuk mengajak pembaca agar tidak turut memojokkan pemerintah pada isu rupiah yang terjadi.

\section{SIMPULAN}

Berdasarkan hasil penelitian analisis framing yang dilakukan dari media online yang menghasilkan empat berita yang diterbitkan oleh media online google terkait isu pelemahan rupiah, maka berikut kesimpulan yang peneliti temukan. 
Dilihat dari struktur sintaksis, 3 berita online fokus pada pembahasan mengenai melemahnya rupiah sedangkan 1 berita online yang diterbitkan oleh Kompas.com fokus pada pembahasan melemahnya rupiah yang dikaitkan dengan politik.

Dari struktur skrip, media online Tribunnews.com, Liputan.com, Detik.com, dan Kompas.com memiliki kelengkapan dalam segi unsur beritanya $(5 \mathrm{~W}+1 \mathrm{H})$.

Dari sisi tematik, keempat media mengisahkan fakta pada informasi yang masing-masingnya memiliki fokus informasi yang berbeda.

Dari sisi retoris, Kompas.com menggunakan kata yang ekstrem yaitu dengan adanya penggunaan kata "menggoreng" yang dikutip oleh wartawan dalam menunjukkan pernyataan dari narasumber.

Media Kompas.com memiliki isi pemberitaan yang ingin memanaskan isu rupiah dengan politik dilihat dari adanya sentimen pernyataan yang diberikan dengan kata "menggoreng".

\section{DAFTAR PUSTAKA}

Amirullah. (2018). Lawan Politik Gunakan Isu Ekonomi, PDIP: Malah Bagus!.

Diakses tanggal 8 Februari 2019 pukul 08.00, dari

https://www.nasional.tempo.co/

Anto, K. (2018). Tren Baru Politik; Cari Kesalahan Lawan dan Goreng Isu SARA.

Retrieved from https://pepnews.com/2018/04/14/tren-baru-politik-cari-

kesalahan-lawan-dan-goreng-isu-sara

Hidayat, Ali A.N. (2018). 2019, Isu Ekonomi Diprediksi Modal Serangan Politik

Ke Jokowi. Diakses tanggal 8 Februari 2019 pukul 08.00, dari

https://www.bisnis.tempo.co/

Johansyah, Difi A. (2013). Gerai Info Bank Indonesia. Diakses pada tanggal 8

Februari 2019 pukul 14.49, dari http://www.BI.go.id//

Putra. (2013). Data krisis 2018 rupiah. Diakses pada tanggal 8 Februari 2019

pukul 14.00, dari http://www.merdeka.com//

Chykina, V., \& Crabtree, C. (2018). Using Google Trends to Measure Issue

Salience for Hard-to-Survey Populations, 0-2.

https://doi.org/10.1177/2378023118760414

Sugiarto, Toto. (2014). Media Sosial Dalam Kampanye Politik. Diakses pada tanggal 8 Februari 2019 pukul 12.00, dari https://nasional.kompas.com// 
Supratikno, Hendrawan. (2018). Dolar AS Capai Rp 14.800 di Era Jokowi Apa Dampaknya Ke Politik. Diakses pada 8 Februari 2019 pukul 11.00, dari http://news.detik.com//

McQuail, D. (2011). Teori Komunikasi Massa. (P. I. Izzati, Ed.) (6th ed.). Jakarta: Salemba Humanika.

Eriyanto. (2002). Analisis Framing. (N. Huda, Ed.) (I). Yogyakarta: LKiS Yogyakarta.

Pan, Z., \& Kosicki, G. M. (2010). Framing analysis : An approach to news discourse Framing Analysis : An Approach to News Discourse, (December 2012), 37-41

Edward, B., \& Publishing, E. (1997). Peter Golding, Graham Murdock ( Hg .): The Political Economy of the Media, I, 41-42.

Mathari, R. (2018). Karena Jurnalisme Bukan Monopoli Wartawan. (W. P. Utomo, Ed.). Yogyakarta: Mojok.

Wendratama, E. (2017). Jurnalisme Online : Panduan Membuat Konten Online Yang Berkualitas dan Menarik. Yogyakarta: Bentang Pustaka.

Harahap, A. (2018). Manajemen Pemberitaan dan Jurnalistik TV. (B. Sarwiji, Ed.). Jakarta Barat: Indeks Jakarata.

Bungin, B. (2008). Konstruksi Sosial Media Massa. Jakarta: Kencana Prenada Media Group.

Sobur. (2012). Framing Analysis: An Approach to news discourse . Metodologi Penelitian. Yogyakarta: Rake Sarakin. 2016.

Mulyana, Deddy. Metodologi Penelitian Kualitatif: Paradigma Baru Ilmu Komunikasi dan Ilmu Sosial Lainnya. Bandung: Remaja Rosdakarya. 2001.

Neuman, W. Lawrence. Social Research Methods: Qualitative and Quantitative Approach. New York: Pearson Education, Inc. 2003.

Saukko, Paula. New Ethnography and Understanding The Other Doing Research in Cultural Studies. London: Sage Publication. 2003.

Spradley, James P. Metode Etnografi (Terjemehan Misbah Zalfa Elizabeth). Yogyakarta: Tiara Wacana. 2006. 


\section{LAMPIRAN}

\section{BERITA 1}

Gubernur BI Soal Pelemahan Rupiah: Fundamentalnya Harusnya Tidak Selemah Ini Rabu, 5 September 2018 09:17 WIB

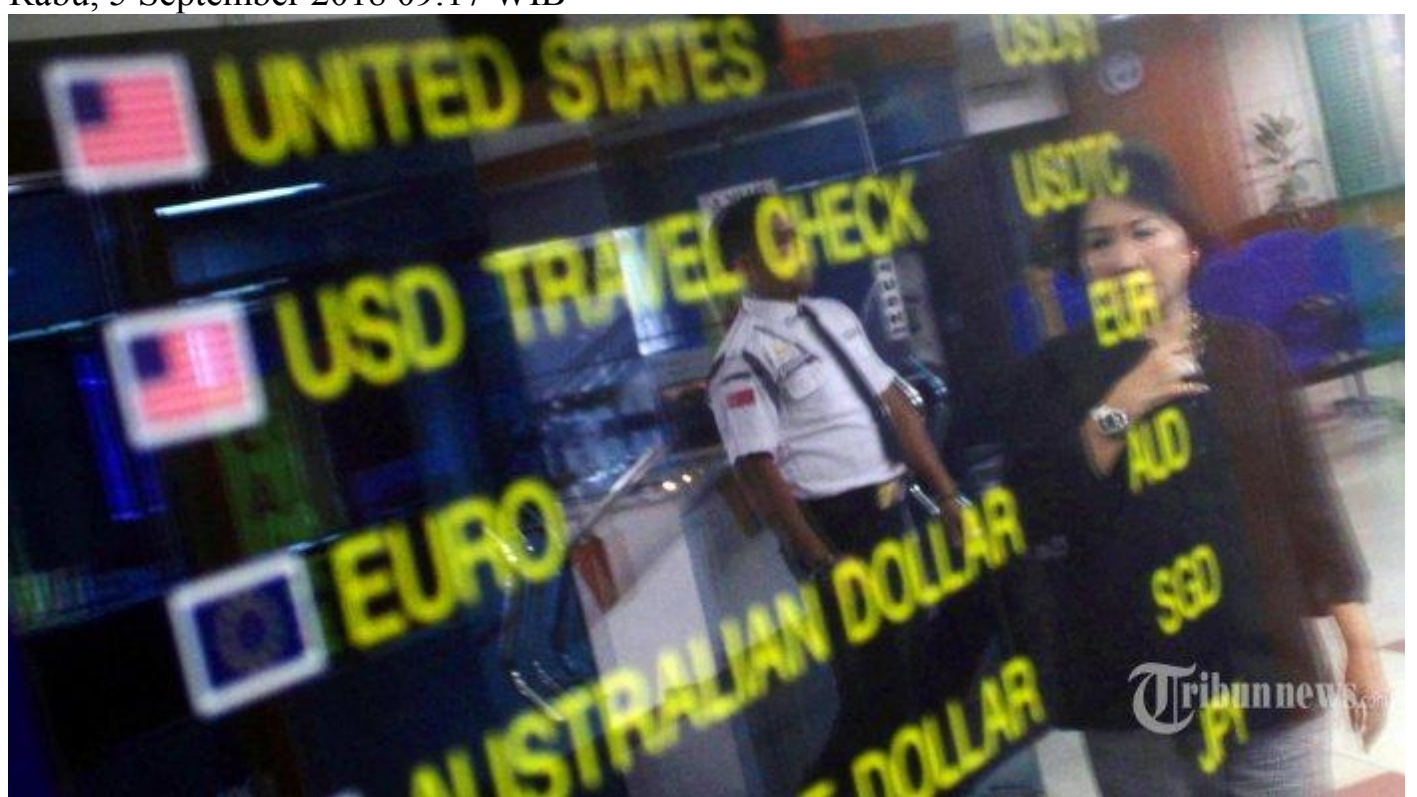

TUKAR DOLAR - Suasana pertukaran uang PT Ayu Masagung Jalan Kwitang, Jakarta Pusat, Selasa (4/9/2018). Banyak orang yang menjual uang dollarnya dan tak sedikit juga orang yang membeli dollar karena takut semakin naik nilai tukar dollar AS mendekati 15.000 rupiah. (Warta Kota/Henry Lopulalan)

TRIBUNNEWS.COM, JAKARTA - Nilai tukar rupiah melemah.

Data Reuters pada Selasa (4/9/2018) pukul 6.12 sore menunjukkan, nilai tukar Rupiah berada di Rp 14.954 per dollar AS.

Bahkan pantauan pada sejumlah bank besar, kurs jual dollar AS sudah menembus Rp 15.000 .

Dari 10 bank besar, kurs jual dollar AS di tujuh bank sudah melewati Rp 15.000.

Kendati demikian, dalam berita yang dilansir dari Kontan.co.id Bank Indonesia (BI) menilai, nilai tukar rupiah yang saat ini merosot sudah keluar dari fundamentalnya.

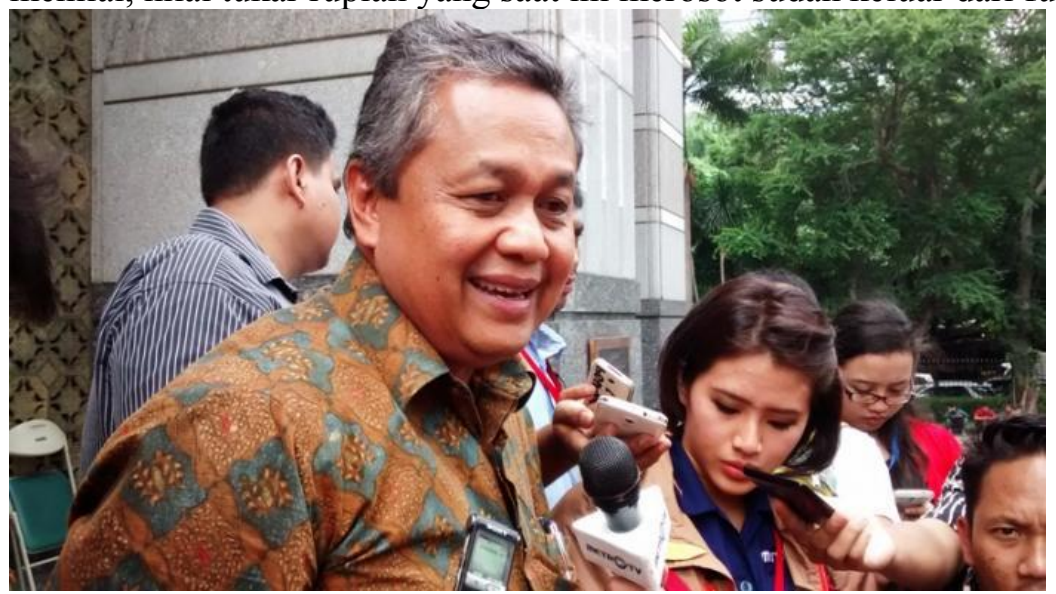


Gubernur BI Perry Warjiyo (Tribunnews.com/Sylke Febrina Laucereno)

"Betul bahwa rupiah ini tergantung juga dengan sentimen pasar, tetapi hitungan fundamentalnya harusnya tidak selemah ini," kata Gubernur BI Perry Warjiyo di Gedung DPR RI, Selasa (4/9).

Menurut Perry, pelemahan nilai tukar rupiah banyak dipengaruhi oleh sentimen negatif baik di luar negeri maupun dalam negeri.

Dari luar negeri, misalnya kenaikan Fed Fund Rate, tekanan dari Argentina dan Turki serta isu perang dagang.

Sementara dari domestik adalah pembelian valas oleh korporasi untuk impor yang masih besar.

Untuk sentimen yang datangnya dari dalam negeri, Perry mengimbau agar pelaku ekonomi dalam negeri tidak perlu menubruk dollar AS.

"Kami sampaikan ke importir dan korporasi yang butuhkan valas tidak perlu menubruknubruk. Kami sudah sediakan swap. Swap Jumat lalu, targetnya US\$ 400 juta dan realisasinya US\$ 850 juta. Kami juga di BI komitmen stabilkan rupiah dan meningkatkan intensitas intervensi kami," jelasnya.

Asal tahu saja, untuk mencegah nilai tukar rupiah merosot lebih dalam, BI terus berada di pasar untuk menaikkan volume intervensi baik di pasar valas maupun di pasar SBN.

Perry mengatakan, sejak Kamis (30/8), BI telah masuk ke pasar sekunder SBN.

"Kamis dan Jumat lalu maupun kemarin (Senin 3 September 2018) kami beli SBN. Jumat kami beli SBN Rp 4,1 triliun yang dijual asing. Kemarin (Senin) kami beli dari pasar sekunder Rp 3 triliun," ujar Perry di Gedung DPR RI, Selasa (4/9/2018).

Dengan demikian, bila dihitung, BI sudah mengeluarkan Rp 7,1 triliun untuk intervensi SBN di pasar sekunder.

Selain itu, Perry mengatakan, dengan fokus jangka pendek bank sentral yang lebih kepada stabilisasi khususnya rupiah, BI juga telah menaikkan suku bunga acuan menjadi 5,5\% sejak awal tahun ini. Hal ini juga merupakan upaya stabilkan nilai tukar.

"Ini agar imbal hasil aset-aset keuangan khususnya SBN tetapi menarik," ucapnya.

Dengan menaikkan suku bunga acuan, kata Perry, masih terjadi masuknya aliran modal asing pada Juli-Agustus lalu.

\section{BERITA 2}

\section{Alasan Pelemahan Rupiah Saat Ini Berbeda dengan 1998}

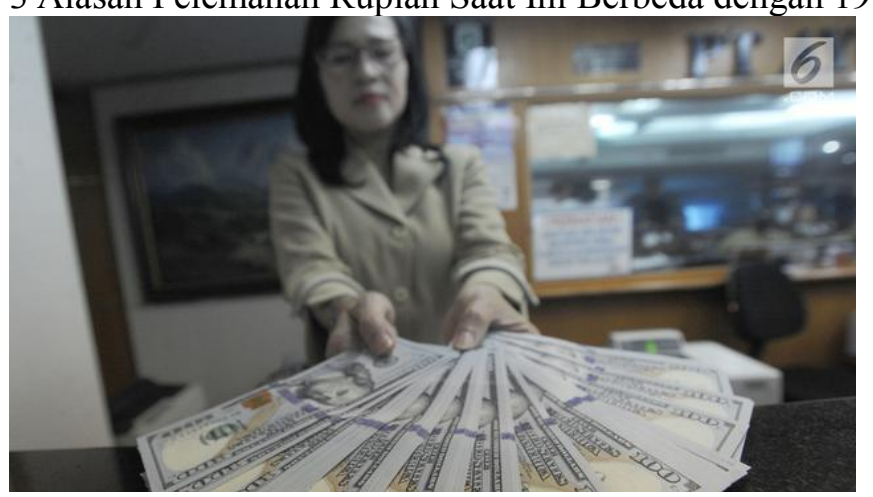

Petugas menunjukkan uang dolar AS di gerai penukaran mata uang di Ayu Masagung, Jakarta, Senin (13/8). Pada perdagangan jadwal pekan, senin (13/08). Nilai tukar rupiah terhadap dolar AS menyentuh posisi tertingginya Rp 14.600. (Merdeka.com/Arie Basuki) Liputan6.com, Jakarta - Nilai tukar rupiah terhadap dolar AS terus bergerak melemah. 
Pada perdagangan Selasa ini, rupiah menyentuh angka 15.000 per dolar AS yang merupakan level terendah dalam 20 tahun terakhir.

Deputi III Bidang Kajian dan Pengelolaan Isu-isu Ekonomi Strategis Kantor Staf Presiden Republik Indonesia Denni Puspa Purbasari menjelaskan, meskipun pelemahan rupiah semakin dekat dengan level pada saat krisis moneter 1998, tetapi rupiah saat ini sebenarnya sangat jauh berbeda dibandingkan dengan situasi saat krisis, dua dekade silam tersebut.

Menurut Denni, setidaknya, ada tiga alasan yang menjadi buktinya. Berikut penjelasannya:

\section{Pelemahan tidak drastis}

Pelemahan rupiah yang terjadi saat ini relatif berlangsung secara perlahan dan tidak drastis. Sejak awal tahun hingga level terendahnya, rupiah melemah 9,3 persen. Hal ini sangat berbeda dengan saat krisis 1998.

Tahun itu, pada 17 Juni, rupiah mencapai level terendahnya, 15.250 per dolar AS.

Dihitung dari sejak awal tahun, nilai tukar rupiah terjun 124,39 persen.

"Volatilitas pergerakan nilai tukar rupiah terhadap dolar AS selama krisis 1998 juga sangat tinggi dan bergerak dalam rentang yang lebar," jelas dia dikutip dari keterangan tertulis, Selasa (4/9/2018).

Perinciannya, pada 1997, rupiah bergerak di kisaran 2.362 - 5.850 per dolar AS. Adapun, fluktuasi harga harian sepanjang tahun itu bisa menguat 12,26 persen dan melemah 13,21 persen.

Tahun 1998, rupiah bergerak pada rentang 5.650 - 15.250 per dolar AS. Dalam satu hari, rupiah bisa menguat 20,66 persen atau melemah 24,11 persen.

Nilai rupiah yang terjun bebas, diikuti dengan fluktuasi yang tinggi, ketika itu membuat hitungan bisnis kacau dan masyarakat panik.

Berbeda dengan kondisi sekarang, di mana pelaku usaha seharusnya masih bisa menyerap efek dari pelemahan rupiah yang tidak drastis dengan volatilitas yang relatif tidak terlalu tinggi.

\section{Cadangan Devisa Jauh Lebih Besar}

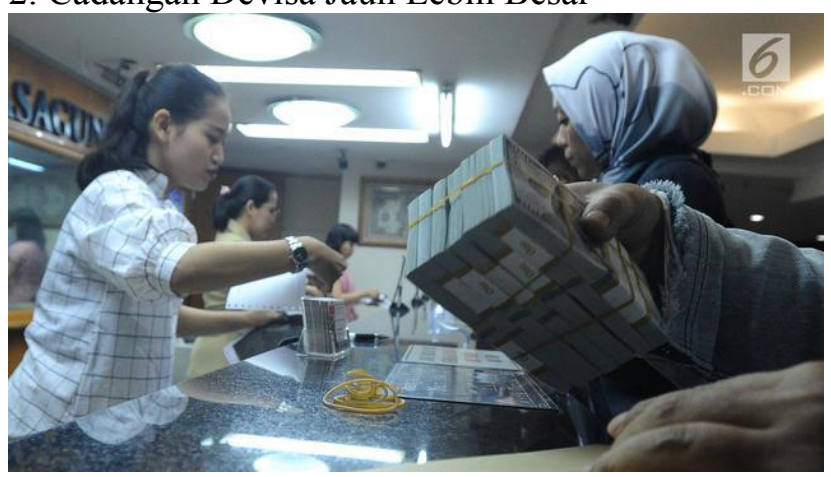

Petugas melayani nasabah di gerai penukaran mata uang di Ayu Masagung, Jakarta, Senin (13/8). Pada perdagangan jadwal pekan, senin (13/08). Nilai tukar rupiah terhadap dolar AS menyentuh posisi tertingginya Rp 14.600. (Merdeka.com/Arie Basuki)

Kendati turun dari posisi akhir tahun 2017, posisi cadangan devisa saat ini masih jauh lebih besar dibandingkan dengan kondisi saat krisis 1998.

Saat itu, cadangan devisa Indonesia hanya mencapai US\$23,61 miliar. Sedangkan, per akhir Juli 2018, cadangan devisa mencapai US\$ 118,3 miliar. Itu berarti, lima kali lipat lebih besar ketimbang cadangan devisa 20 tahun silam.

Dengan cadangan devisa yang jauh lebih besar, bank sentral memiliki lebih banyak "modal" untuk meredam gejolak nilai tukar. 
"Melihat pelemahan hari ini, misalnya, BI turun mengintervensi pasar sehingga pelemahan rupiah tidak terlalu dalam," kata dia.

Singkatnya, masyarakat, termasuk pelaku pasar dan dunia usaha, tidak perlu khawatir rupiah akanterpuruk. Sebab, Bank Indonesia ada di pasar untuk menjaga stabilitas rupiah. Di samping itu, pemerintah turut mendukung kebijakan Bank Indonesia dalam mengawal rupiah.

"Pemerintah tidak akan mengintervensi Bank Indonesia. Pemerintah terus berkoordinasi dengan Bank Indonesia, OJK (Otoritas Jasa Keuangan), dan LPS (Lembaga Penjamin Simpanan)," ujar Denni.

\section{Kepercayaan Investor Masih Kuat}

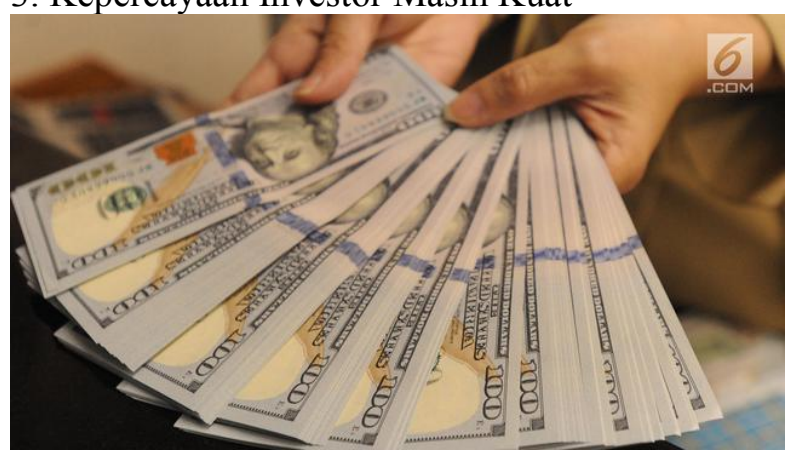

Petugas menunjukkan uang dolar AS di gerai penukaran mata uang di Ayu Masagung, Jakarta, Senin (13/8). Pada perdagangan jadwal pekan, senin (13/08). Nilai tukar rupiah terhadap dolar AS menyentuh posisi tertingginya Rp 14.600. (Merdeka.com/Arie Basuki)

Minat investasi asing terhadap surat utang suatu negara merupakan salah satu indikator yang secara tidak langsung memperlihatkan baik buruk kondisi makroekonomi suatu negara. Logikanya, tidak ada investor yang mau menempatkan uangnya di negara yang tengah sakit.

Ketika bank sentral AS mengerek suku bunga, memang terlihat investor asing menarik dananya dari pasar surat utang Indonesia. Namun, sejak awal bulan ini, asing kembali masuk ke pasar surat utang.

Bahkan, per akhir pekan lalu, asing mencatatkan beli bersih Surat Berharga Negara (SBN) sebesar Rp 6,92 triliun. Itu berarti, kepercayaan investor asing terhadap Indonesia masih kuat. Ini memberi harapan, nilai rupiah ke depan akan cenderung stabil atau tidak akan jatuh terlalu dalam.

Memperkuat keyakinan itu, lembaga pemeringkat utang Fitch Ratings mengafirmasi peringkat BBB untuk surat utang Indonesia dengan outlook stabil. Peringkat ini menunjukkan Indonesia termasuk di dalam kategori layak investasi.

"Pemerintah akan memastikan bahwa fiskal bukan sumber dari ketidakpasatian," Denni menegaskan.

\section{BERITA 3}

\section{Ini Bedanya Pelemahan Rupiah 2018 dan Krismon 1998}




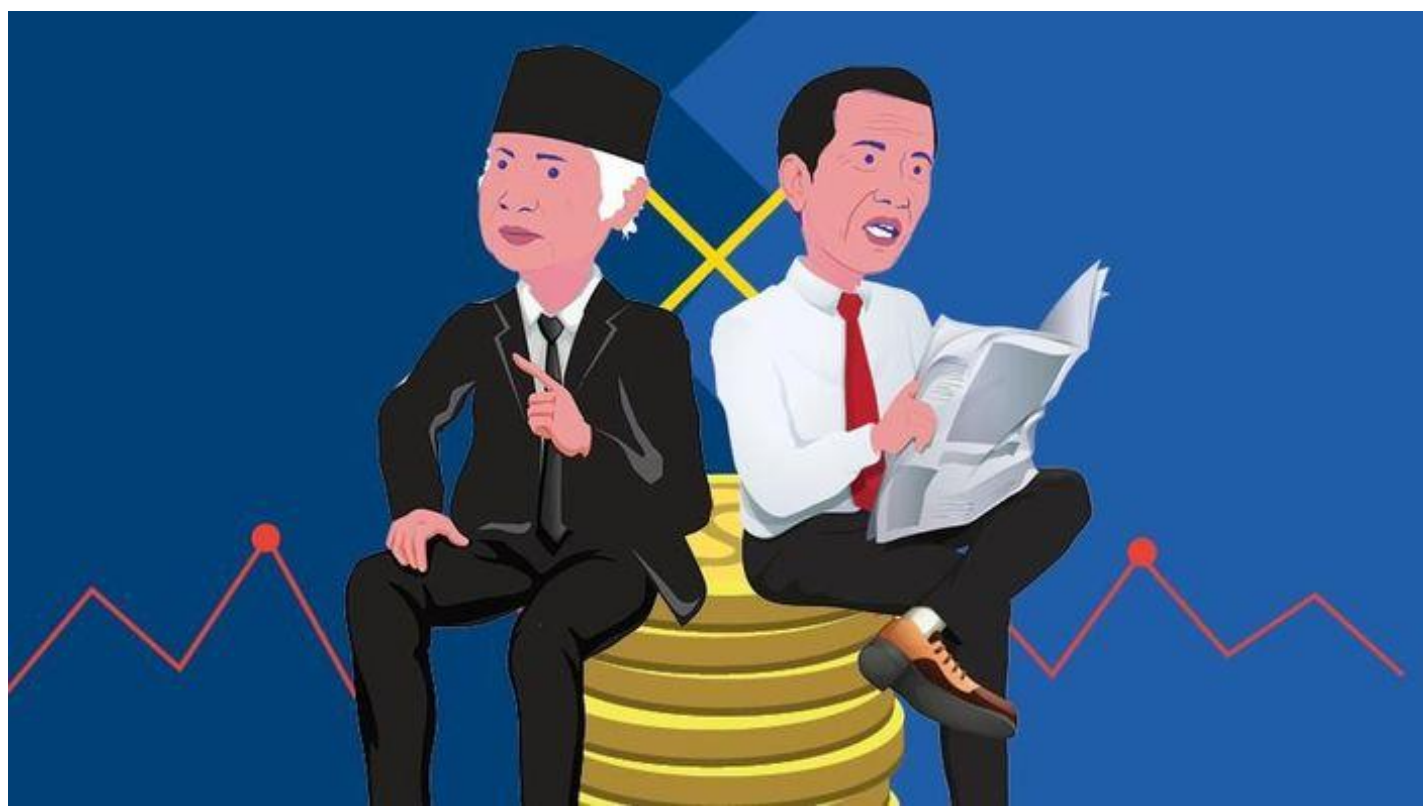

Jakarta - Rupiah terus mengalami tekanan dari dolar Amerika Serikat (AS).

Perdagangan dolar AS hari ini sudah mencapai posisi Rp 14.897. Waktu krisis 1998 nilai dolar AS berada di kisaran Rp 16.500.

Apa iya Indonesia menuju krisis? Jika tidak apa bedanya nilai Rupiah kini dan 20 tahun lalu?

Presiden Direktur PT Bank Central Asia Tbk (BCA) Jahja Setiaatmadja menjelaskan kondisi Indonesia saat ini tidak mirip dengan era 97-98. Menurut dia 20 tahun lalu ada masalah politik yang kuat dan terlalu runyam.

"Kalau sekarang itu Indonesia, sepenuhnya masalah ekonomi dan sentimen global," kata Jahja kepada detikFinance, Selasa (4/9/2018).

Jahja mengharapkan, isu ekonomi ini tidak dijadikan bahan untuk politik, meskipun di dunia politik semua cara dihalalkan.

"Harapan saya jangan lah, kalau NKRI hancur kan kita rakyat sama-sama menanggung rugi, padahal sekarang lagi bagus. Menurut saya, kalau tidak ada faktor eksternal atau global ini Indonesia masih bagus ekonominya, tidak ada yang mengganggu kepercayaan masyarakat," ujarnya.

Ekonom PermataBank Josua Pardede menjelaskan, saat ini nilai tukar sebagian negara berkembang cenderung terkoreksi terhadap dolar AS, namun kondisi ini masih jauh dari krisis 1998.

Dia menjelaskan kondisi fundamental perekonomian Indonesia sekarang sangat berbeda dengan kondisi fundamental pada tahun 1998. Saat itu krisis yang berawal dari krisis mata uang Thailand Bath juga diperburuk dengan pengelolaan utang luar negeri swasta yang tidak prudent karena sebagian utang luar negeri swasta tidak memiliki instrumen lindung nilai.

Josua mengungkapkan, saat itu penggunaan utang jangka pendek untuk pembiayaan 
usaha jangka panjang, serta utang luar negeri yang dipergunakan untuk pembiayaan usaha yang berorientasi domestik.

"Krisis utang swasta pada 1997-1998 tersebut yang mendorong tekanan pada rupiah di mana tingkat depresiasi rupiah mencapai sekitar $600 \%$ dalam kurun waktu kurang dari satu tahun, yaitu dari Rp 2.350 per dolar menjadi Rp 16.000 per dolar," kata Josua.

Sementara jika melihat kondisi fundamental Indonesia pada tahun ini, pengelolaan utang luar negeri swasta cenderung lebih berhati-hati dimana Bank Indonesia juga sudah mewajibkan transaksi lindung nilai bagi korporasi dalam rangka mengelola risiko nilai tukar.

"Pengelolaan yang lebih baik dari utang luar negeri swasta terlihat dari pertumbuhan utang jangka pendek yang cenderung rendah," ujar dia.

Selain itu, jika volatilitas nilai tukar rupiah cenderung meningkat, BI diperkirakan akan kembali lagi memperketat kebijakan moneternya dalam jangka pendek ini untuk meningkatkan kepercayaan pelaku pasar.

Mempertimbangkan perbaikan fundamental ekonomi, afirmasi dari Fitch terhadap peringkat utang Indonesia yang masih layak investasi dengan outlook stable, maka pemerintah dan BI diperkirakan akan dapat mengelola stabilitas rupiah sehingga dapat meredam pelemahan rupiah di bawah level Rp 15.000 per dolar AS.

Ekonom INDEF Bhima Yudhistira Adhinegara menjelaskan kondisi saat ini dan 98 berbeda. Meskipun sama-sama dipicu krisis mata uang negara berkembang. Saat 1998 krisis dimulai dari Thailand dan tahun ini dimulai dari Turki dan Argentina.

Menurut Bhima, dari kesiapan Indonesia menghadapi krisis terlihat dengan perbaikan rating utang yang signifikan. Tahun 1998 rating Fitch anjlok hingga B- dengan outlook Negatif. Tahun 2018 per September Fitch memberikan rating utang BBB dengan outlook Stabil.

Kemudian kinerja pertumbuhan ekonomi 1998 merosot ke -13,6\%. Saat ini pertumbuhan ekonomi berada di 5,2\% per triwulan II 2018. Inflasi sempat naik hingga 77\% saat krisis moneter.

"Sekarang cukup stabil di bawah 3,5\%. Pelemahan kurs rupiah belum terlihat dampaknya pada Agustus 2018 yang justru mencatat deflasi," imbuh dia.

Kemudian cadangan devisa tahun 1996 sebelum krisis berada di angka US\$ 18,3 miliar. Saat ini cadev di kisaran US\$ 118,3 miliar.

"Kemampuan BI untuk intervensi rupiah melalui cadangan devisa jauh di atas kemampuan tahun 1996 sebelum menghadapi krisis," ujarnya.

Meskipun beberapa indikator menunjukkan perbaikan. Tapi pemerintah harus mewaspadai defisit transaksi berjalan yang menembus 3\% pada kuartal II 2018.

"Negara dengan defisit transaksi berjalan sangat rentan terpapar krisis ekonomi. Seperti 
Turki dan Argentina yang kedua nya memiliki defisit transaksi berjalan yang cukup lebar," imbuh dia.

\section{BERITA 4}

\section{Ketua DPD Sesalkan Pelemahan Rupiah Jadi Alat Politik untuk Serang Pemerintah}

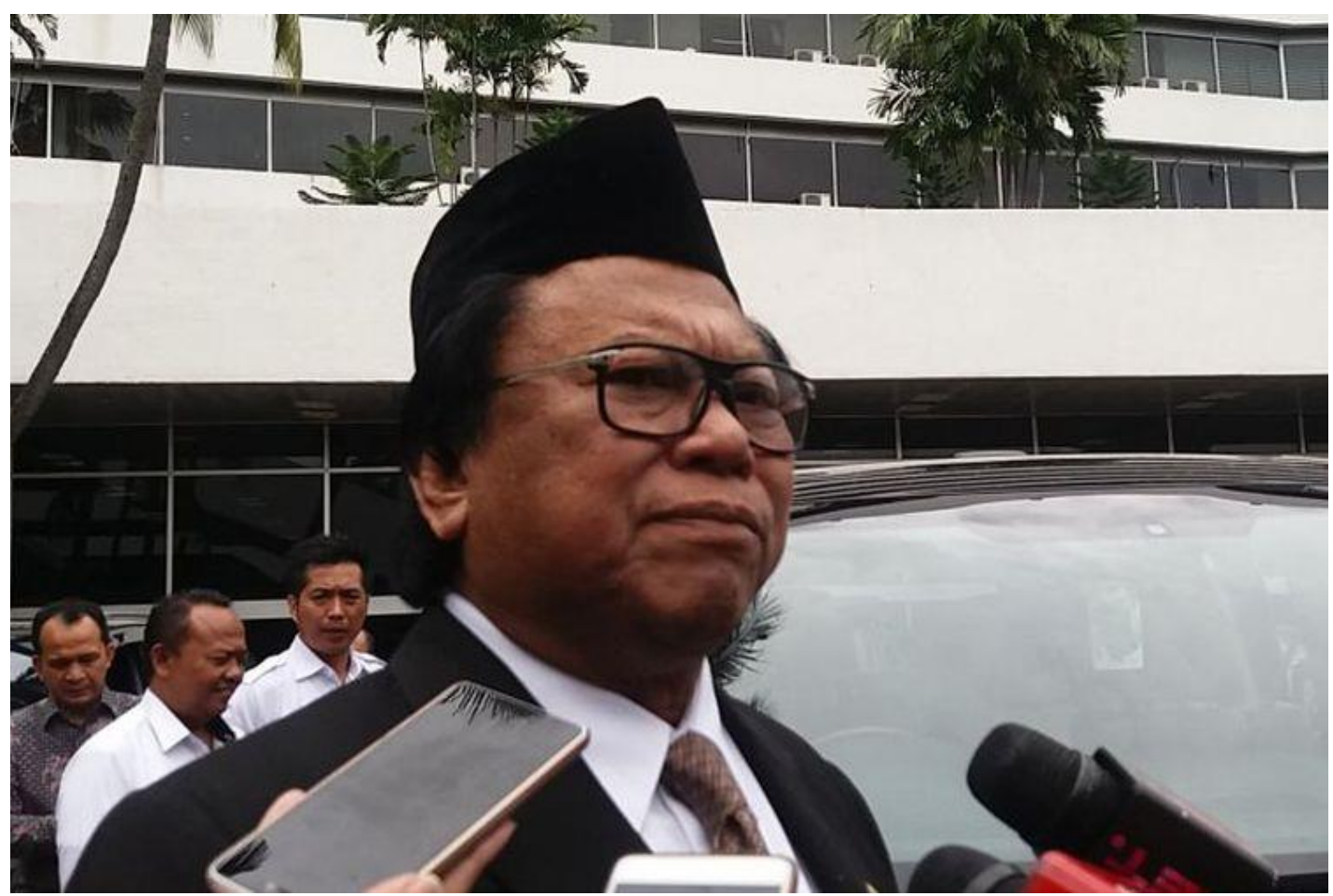

IHSANUDDIN Kompas.com - 06/09/2018, 16:28 WIB Ketua DPD RI Oesman Sapta

Odang di Kompleks Parlemen, Senayan, Kompleks Parlemen, Senayan, Jakarta, Kamis

(14/12/2017)(KOMPAS.com/Nabilla Tashandra)

JAKARTA, KOMPAS.com - Ketua Dewan Perwakilan Daerah Oesman Sapta meminta semua pihak tak terus-menerus menggoreng isu kenaikan dollar Amerika Serikat (AS) dan memojokkan pemerintah. Menurut dia, kenaikan dollar AS merupakan siklus perekonomian dunia, bukan karena persoalan ekonomi dalam negeri. Oesman mengatakan, pernyataan-pernyataan yang dikeluarkan sejumlah politisi terkait kenaikan dollar AS dan turunnya nilai rupiah karena ingin menjatuhkan kredibilitas pemerintah. Tujuannya, agar rakyat tak lagi percaya terhadap pemerintah yang dinilainya telah bekerja keras menjaga rupiah. Baca juga: Pelemahan Rupiah Tak Separah 1998, Ini Sebabnya "Pandangan negatif yang dialamatkan kepada pemerintah cenderung politis. Ada sasaran politik, supaya rakyat terpengaruh. Namun, saya yakin, rakyat tidak terpengaruh dengan ocehan yang tidak realistis," ujar Oesman melalui keterangan tertulisnya, Kamis (6/9/2018). Dia mengatakan, melemahnya nilai tukar rupiah terhadap dollar AS karena krisis perekonomian global. Menurut dia, sisi fundamental ekonomi dalam negeri masih sangat kuat. Oesman Sapta meminta masyarakat mengkhawatirkan melemahnya nilai tukar rupiah. Dia yakin, masalah itu bakal segera teratasi dengan baik. "Apa yang terjadi saat ini, bukan masalah perekonomian dalam negeri. Ini siklus ekonomi dunia. Dan kita sudah memiliki sistem yang kuat untuk melewatinya," kata dia. Baca juga: Anies: Jangan Khawatir, Program DP 0 Rupiah Jalan Terus Ia mengatakan, melemahnya nilai tukar tak hanya dialami Indonesia. Bahkan, nilai tukar Turki anjlok 80 persen, Argentina 56 persen, dan Inggris 5 persen. "Yang hebat adalah Jepang, minus dua persen. Sama dengan 
Meksiko. Dulu Meksiko paling jelek, sekarang bisa (bangkit). Artinya, ini disebabkan siklus ekonomi dunia," ujar Oesman Sapta, yang biasa OSO. OSO juga menyesalkan sikap orang-orang yang tidak memahami persoalan ekonomi tapi banyak bicara soal melemahnya nilai tukar. "Sistem ini mau dirusak oleh pihak-pihak yang melawan pemerintah. Saya menyesalkan, pelemahan nilai tukar dijadikan 'alat politik' untuk memengaruhi, mengajak rakyat untuk menyalahkan pemerintah. Kalau mereka mau jujur, apa yang dilakukan pemerintah kan sudah benar," kata senator asal Kalimantan Barat ini. Ia meyakini, perekonomian Indonesia akan semakin kuat setelah melewati siklus ini. Penulis : Ihsanuddin EditorInggried Dwi Wedhaswary

\section{LAMPIRAN PENCARIAN GOOGLE}

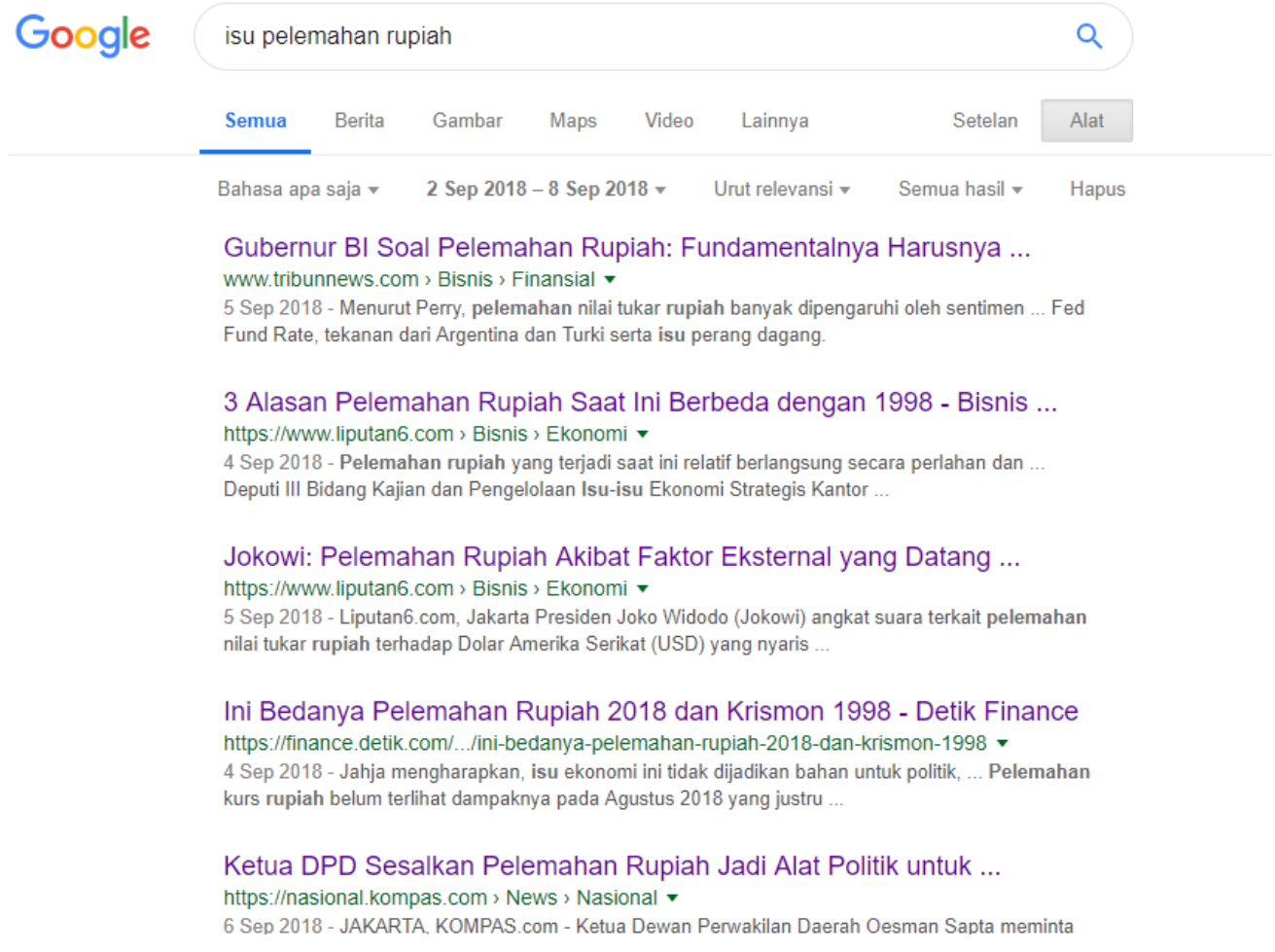




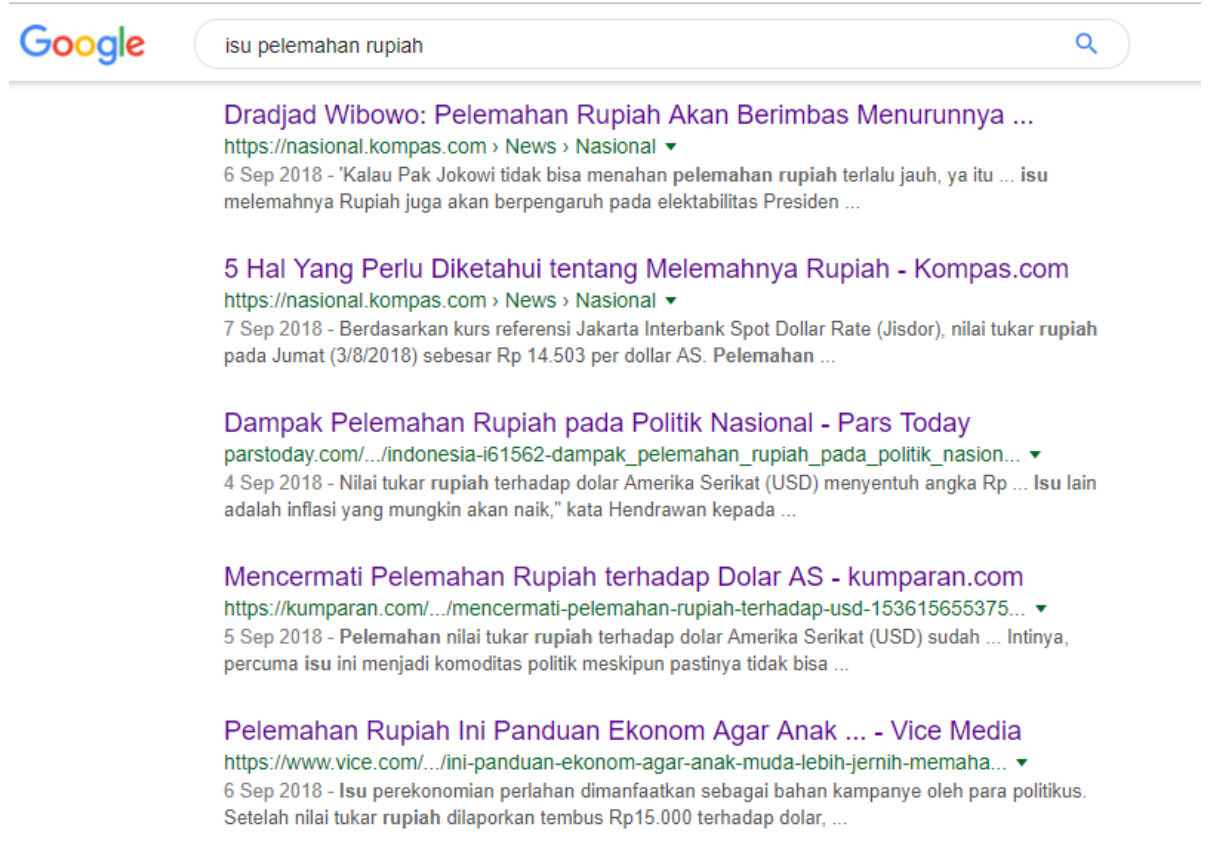

\section{LAMPIRAN TREND RUPIAH DI PENCARIAN GOOGLE}

$\equiv$ Google Trends Pelajari
$\begin{aligned} & \text { rupiah } \\ & \text { Istilah penelusuran }\end{aligned}$
\[ \begin{array}{l}\text { Semua kategori } \\ \text { Indonesia }\end{array} \]
12 bulan terakhir

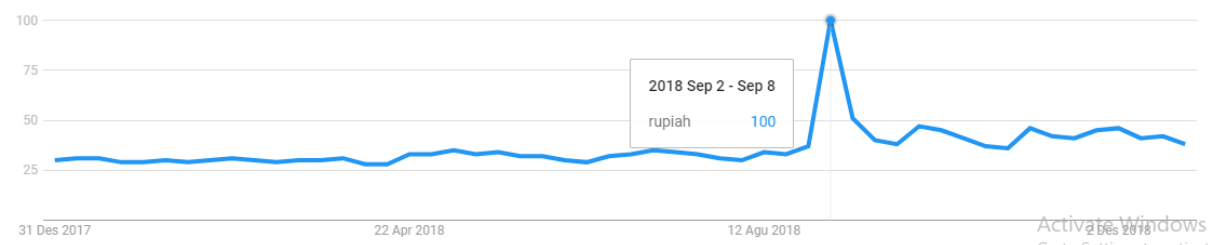

